$9-1-2011$

\title{
Entrepreneurial Orientation, Management Commitment, And Human Capital: The Internationalization Of SMEs In India
}

\author{
Rajshekar G. Javalgi \\ Cleveland State University, r.javalgi@csuohio.edu \\ Patricia R. Todd \\ Western Kentucky University
}

Follow this and additional works at: https://engagedscholarship.csuohio.edu/bus_facpub

Part of the Entrepreneurial and Small Business Operations Commons

How does access to this work benefit you? Let us know!

\section{Publisher's Statement}

NOTICE: this is the author's version of a work that was accepted for publication in the Journal of Business Research. Changes resulting from the publishing process, such as peer review, editing, corrections, structural formatting, and other quality control mechanisms may not be reflected in this document. Changes may have been made to this work since it was submitted for publication. A definitive version was subsequently published in Journal of Business Research, 64, 9, 09-01-2011, 10.1016/j.jbusres.2010.11.024

\section{Original Published Citation}

Javalgi, R.G. \& Todd, P.R. (2011). Entrepreneurial orientation, management commitment, and human capital: The internationalization of SMEs in India. Journal of Business Research, 64(9), 1004-1010. doi:10.1016/j.jbusres.2010.11.024

This Article is brought to you for free and open access by the Monte Ahuja College of Business at EngagedScholarship@CSU. It has been accepted for inclusion in Business Faculty Publications by an authorized administrator of EngagedScholarship@CSU. For more information, please contact library.es@csuohio.edu. 


\title{
Entrepreneurial orientation, management commitment, and human capital: The internationalization of SMEs in India
}

\author{
Rajshekhar (Raj) G. Javalgi a,*, Patricia R. Todd ${ }^{\text {b }}$ \\ a Cleveland State University, United States \\ ${ }^{\mathrm{b}}$ Western Kentucky University, United States
}

\section{Introduction}

In developing and emerging economies, small and medium-sized enterprises (SMEs) play an important role as they represent a major source of employment and generate significant revenue and export earnings. SMEs now have access to new technology and their ability to embrace risk and uncertainty allows them to take advantage of their entrepreneurial and human capabilities, improving their ability to enter challenging new business environments. Existing empirical studies suggest that entrepreneurship influences superior firm performance in the developed economies (Luo et al., 2005). Much research exists focusing on understanding the practice of entrepreneurship in advanced economies (Luo et al., 2005; McDougall and Oviatt, 2000). There is less research addressing the increasing role of entrepreneurial firms in emerging markets (Bruton et al., 2008; Luo et al., 2005; Todd and Javalgi, 2007). This study focuses on filling this gap in response to the recommendation made by Zahra and George (2002), who propose the impact of entrepreneurial orientation, firm's resources (e.g., human capital) and commitment to internationalization on the international expansion firms should be extended beyond advanced economies.
When examining the entrepreneurship literature dealing with emerging markets, India has been the focus of only one study in the last past 15 years (e.g., Bruton et al., 2008). The purpose of this research is to extend the literature addressing the relationships surrounding the internationalization of SMEs in emerging markets such as India. The key research questions addressed in this study are follows: How does entrepreneurial orientation and management commitment affect the degree of internationalization of Indian SMEs? Does human capital matter? What is the impact of market turbulence on international activities? Addressing these questions is increasingly important as small and medium-sized businesses, particularly in an emerging market as found in India, develop competitive strategies for operating in a global environment. This article focuses on factors influencing the success of Indian SMEs as they attempt to expand internationally.

India is the focal country for this study for the following reasons: India's economy has experienced tremendous growth since liberalization efforts, beginning in the 1980s. In India, SMEs contribute 7 percent to gross domestic product (GDP), make up 34\% of national exports, and account for $40 \%$ in the manufacturing sector (Venkataramany, 2008). While most countries put small entrepreneurial firms with less than 500 employees in the category of SMEs, in India these firms are small-scale industries (SSI).

\section{Related literature review on internationalization}

The term internationalization broadly encompasses a number of issues (Benito et al., 2009; Buckley and Casson, 2009; Leonidou et al., 
1998). Calof and Beamish (1995) define internationalization as "the process of adapting a firm's operations (strategy, structure, and resource, etc.) to environments" (p. 116). According to Buckley and Casson (2009), internationalization is a general principle that explicates the boundaries of organization. These authors further define the internationalization concept by combining it with trade theory, explaining the location of the firm's operations, with organization theory explaining international joint ventures, and with the international entrepreneurship theory explaining international expansion activities. Buckley and Casson (1976) suggest that firms seek to develop and deploy their resources across international boundaries to take advantage of asymmetries in knowledge and capabilities.

The following categories represent internationalization models/ theories built with different underlying assumptions and structures: The Uppsala/stage Model; The network model; the resource-based view; the OLI framework.

The Uppsala/stage model assumes interplay between the gradual acquisition of knowledge and commitment of resources to international operations (e.g., Johanson and Vahlne (1990). It is experiential knowledge that aids in reducing the firm's perception of market uncertainty, which affects the firm's commitment to internationalization. Therefore, cumulative market knowledge leads the firm to take small, incremental steps to international expansion.

In the network model, the activities in the network allow the firm to form relationships, which help to gain access to resources and markets. Johanson and Mattsson (1988) consider business networks as the relationships a firm establishes with various actors, such as customers, suppliers, and competitors. These authors argue that as the firm's internationalization efforts increase, the number and strength of relationships between different business actors increase, creating access to resources and markets.

The resource-based view (RBV) of the firm has emerged as an important explanation of firm behavior. The firm internationalizes for reasons related to the bundle of resources that managers use to create value. Resources that are valuable, difficult to imitate, and have no substitutes contribute to the firm's unique or core competencies and resulting in a lasting competitive advantage (e.g., Prahalad and Hamel, 1990). A firm's resources consist of all assets tangible and intangible, human and nonhuman, that the firm possesses and that permit the firm to create and apply value-enhancing strategies (e.g., Wernerfelt, 1995). Specifically, intangible firm-specific resources such as human capital and experience permit firms to increase value related to incoming factors of production and create competitive advantage for a firm (e.g., Prahalad and Hamel, 1990).

Dunning (1980) provides an eclectic model (also known as the OLI framework) to explain foreign investment activities by ownership specific advantages $(\mathrm{O})$, location-specific advantages $(\mathrm{L})$, and internalization advantages (I). Ownership advantages are firm-specific resources or capabilities (e.g., international experience), while location specific advantages (e/g., market potential) refer to the institutional and productive factors present in a particular country/ market. The internalization advantages depend on the foreign firm's capacity to manage and coordinate activities internally (Dunning, 1981).

Market entry decisions may depend on offshore outsourcing (e.g., Javalgi et al., 2009). The phenomenon of offshore outsourcing would seem to both reaffirm and challenge the OLI framework (e.g., Doh, 2005). For instance, location is an important variable for marketseeking, resource-seeking, and cost-minimization objectives. These are also motivations for offshore outsourcing (Doh, 2005; Javalgi et al., 2009). Offshore outsourcing enhances international competitiveness by enabling SMEs to reduce costs, increase relational ties, and serve customers more effectively (Gregorio et al., 2008). Both as internal process and business strategy, offshore outsourcing could be an outcome of successful management of resources, and may itself represent a direct application of firm-level capabilities as envisioned by RBV (e.g., Doh, 2005).

\section{Hypothesis development}

\subsection{Hypothesis related to human capital and internationalization}

Human capital is critical to economic growth and entrepreneurial opportunities. In relation to internationalization, human capital consists of knowledge, skills, talent and experience used to provide value to the firm (Fletcher, 2004). Recent examination of human capital in strategy literature focuses on human capital as resources of the firm (e.g., Hitt et al., 1997), yet fails to examine a direct causal link between human capital and firm internationalization. The resource based viewpoint (RBV) states that firm specific resources result in a sustainable competitive advantage, creating resources that are valuable, rare, inimitable, and non-substitutable (Barney, 1991). Resources encompass three general capital resource categories: physical, human, and organizational. Physical capital resources encompass physical technology, property, plant, equipment, and access to raw materials.

Human capital resources include the "training, experience, judgment, intelligence, relationships, and insight of individual managers and workers in a firm" (Barney, 1991, p. 101). Organizational capital resources involve the firm's reporting structure, planning processes, control and coordination systems, and information relations among workers within the firm, between firms, and within the business environment.

Human capital theory suggests that firms with a higher degree of human capital developed through access to employees with higher education and expansive personal experience achieve higher performance (Barney, 1991). Human capital is an important source of competitive advantage (Coleman, 1998). Loscocco et al. (1991) suggests that a major determinant of small business success is industry-specific experience. Bosma et al. (2004) notes that in the Netherlands prior experience in an industry substantially improved SMEs' success, growth, and survival. Brush and Chaganti (1998) find that education and industry experience affected firm performance.

Researchers confirm the positive effect of education and international experience on firm internationalization (e.g., Athanassiou and Nigh, 2002; Herrmann and Datta, 2005). Export research also provides support that the prior international experience of export managers is a driver of SME internationalization by influencing the firm's involvement in international export activities (Ibeh and Young, 2001).

In brief, human resources are likely to be more critical and several studies, mostly conducted in the Western economies, provide empirical support for the positive effect of human capital on SMEs internationalization (Patterson and Cicic, 1995; Ruzzier et al., 2007). However, less research has focused on the impact of human capital on the internationalization of SMEs in emerging economies such as India.

H1. Human capital relates positively to the degree of internationalization of Indian SMEs.

\subsection{Hypothesis related to management commitment and internationalization}

International commitment is the extent to which a firm's management has favorable attitude toward, and is willing to deploy necessary resources to internationalization efforts (Cadogan et al., 2005; Leonidou et al., 1998). Top management is the primary force driving the creation of values and beliefs that members of that firm adhere to (Jaworski and Kohli, 1993; McDougall et al., 1994). Therefore, top managers play a key role in shaping an organization's values and orientation. Calof and Beamish (1995) further support this view. In addition, Winsted and Patterson (1998) specifically point out that management commitment is an important motive to expand internationally. 
Not all key decision makers act in an entrepreneurial fashion. A leader with a positive attitude towards internationalization possesses a strong tolerance for cultural diversity, a talent for managing uncertainty, and the ability to lead under constantly changing and complex conditions (Kedia and Mukherji, 1999). Ibeh (2003, p. 53) found that "firms with internationally oriented decision makers are more likely to exhibit high export-entrepreneurial orientation than those lacking internationally oriented decision makers." Herrmann and Datta (2005) investigated the relationships between top management characteristics and internationalization, surveying 112 firms that had minimum sales of $\$ 250$ million including international sales. They concluded that there is a strong association between high performing, internationally diversified firms and top management team characteristics such as flexibility, tolerance for change and acceptance of uncertainty.

Zahra et al. (2005) call attention to the necessity of research concerning internationalization to include cognitive aspects of a manager's motivations. Prior exposure of top management to an international environment promotes uncertainty reduction and lessens the fear of doing business in unknown markets (Ibeh, 2003). A study of Canadian firms, found a significant and positive relationship between the leaders' attitudes towards internationalization and the company's export performance (e.g., Kuivalainen et al., 2004). An international mindset was a fundamental corporate posture linked to positive international performance (Knight, 2001).

H2. Management commitment to internationalization relates positively to the degree of internationalization of Indian SMEs.

\subsection{Hypothesis related to entrepreneurial orientation and internationalization}

Managerial behavior and the operating philosophy of the firm's executive level characterize entrepreneurial orientation, enabling entry into new markets (Covin and Slevin, 1988). Three dimensions most frequently used to describe entrepreneurial orientation are innovativeness, proactiveness, and risk taking (e.g., Wiklund and Shepherd, 2003). Innovativeness refers to supporting creativity, introducing new products and services and developing new processes (Lumpkin and Dess, 1996).

Proactiveness refers to opportunity seeking that involves, for example, introducing new products, services and processes ahead of the competition (Lumpkin and Dess, 1996). The third dimension, risk taking, deals with a tendency to take bold actions, such as entering into new foreign markets (Lumpkin and Dess, 1996). Researchers have used these dimensions in the international context to examine the performance of SMEs (Todd and Javalgi, 2007; McDougall et al., 2003; Wiklund and Shepherd, 2003).

Innovation and risk taking are key dimensions characteristic of entrepreneurial orientation (e.g., Zahra and Garvis, 2000). The SME's act of attempting to participate in an international market constitutes entrepreneurship (Ibeh, 2003). All international activities are entrepreneurial as they represent a combination of acceptance of risk and the ability to innovate, which are characteristics necessary to create value in a global market (Fletcher, 2004).

Evidence of entrepreneurial influences on internationalization is also noted in case studies of entrepreneurial firms (Fletcher, 2004; Kuivalainen et al., 2004; Spence and Crick, 2006). The influence of entrepreneurship on firm internationalization is reported in research findings concerning new ventures (Yiu et al., 2007), "born-global" firms (Knight and Cavusgil, 2004), and small to medium-sized firms (Crick and Jones, 2000). Early development of an entrepreneurial culture positively influences a firm's international intent, allowing a firm to be more capable and willing to pursue international opportunities (Autio et al., 2000; Zucchella et al., 2007).

H3. An Indian SME's entrepreneurial orientation relates positively to the degree of internationalization.

\subsection{Market turbulence}

Yeoh and Jeong (1995) identify that the fit between entrepreneurial orientation and export performance may not be a direct one but may be one moderated by environmental factors. Market turbulence is a dimension determined by the amount of change that occurs within the business environment. The degree of change that the firm faces and the preference of the firm's customers to change over time are of particular interest to researchers (Jaworski and Kohli, 1993). Kaya and Seyrek (2005), find that there was a positive, significant relationship between entrepreneurial orientation and financial performance when market turbulence is high. Kohli and Jaworski (1990) identified the importance of the moderating effect of environmental turbulence. The SMEs' external operating environment consists of all of the domestic factors that affect the firm's business and the foreign influences that can positively or negatively impact the ability to operate (e.g., Ibeh, 2003). Firms not seen as entrepreneurial may be unable to react and adapt to adverse environmental pressures. (Zahra and Neubaum, 1998). Management in firms that see challenges in a positive way will react proactively, willingly taking risks by developing objectives allowing them to operate in the complex environment using strategies that involve innovativeness (Miller, 1983).

Zahra and Neubaum (1998) suggest that firms need to be innovative in response to their external environment. Changes in the external environment may provide new opportunities for the firm and the need for new, innovative strategies that take advantage of these opportunities. Understanding the interface between the firm and the environment in which it must do business contributes to understanding the firm's international expansion strategy. The firm's reaction to market turbulence influences its performance (e.g., Heide and Weiss, 1995).

H4a. Market turbulence moderates the relationship between entrepreneurial orientation and the degree of internationalization is of Indian SMEs.

The complexity of forces in the international environment and the need to respond to these factors create major challenges for SMEs. Therefore, increased uncertainty or turbulence in the export environment should increase an organization's need to leverage human capital (e.g., Rose and Shoham, 2002). Hutchinson et al. (2006) noted that business owners or managers' international experience, exposure to foreign culture, and foreign business practice leads to greater international performance. During increased uncertainly in the export environment, employees' skills, education and industry experience affect international performance (Brush and Chaganti, 1998; Leonidou et al., 1998).

Manolova et al. (2002) observed that the important human capital dimensions for export development are managerial skills, international experience, and the knowledge of the export environment. Previous literature in the export-marketing field also acknowledges that high education levels are associated with internationalization (Cavusgil and Naor (1987)). Turbulent markets, intense completion, changing customers' product preferences, and rapid technological changes increase the need to leverage human capital and actively monitor changes in the environment affecting firm performance (Cadogan et al., 2001; Jaworski and Kohli, 1993).

H4b. Human capital moderates the relationship between entrepreneurial orientation and the degree of internationalization is of Indian SMEs.

\section{Research design}

\subsection{Research instrument}

Churchill's (1979) approach to questionnaire development was employed. In the first phase of the development, the related literature 
was used to develop the survey instrument to collect data. Following this step, pretests were used to assess the face validity of the survey items. The preliminary testing of the survey indicated the need for clarification of a few items in the survey. Although there are multiple domestic Indian languages spoken, English is one of India's official languages and is the dominant language used by Indian businesses and the government of India. Since the sample targets businesses in India, the survey was prepared in English form.

\section{Data collection}

Data consisted of a random cross-sectional industry sample of SMEs located in India. Survey respondents were pre-qualified by telephone and e-mail to verify: (1) employee size less than 500, (2) international business involvement, and (3) respondents were an owner, CEO, or a key international management executive. The data consisted of 150 random responses, representing one for each firm. The majority of SMEs sampled had 25 to 49 employees (nearly 50\%), and the remaining were distributed as follows. Nineteen percent reported between 50 and 100 employees, nearly 20\% reported between 100 and 250, and the remaining noted 250 and 500 employees. Reported annual sales revenue indicates: $31 \%$ earn less than $\$ 100,000$, 39.5\% earn $\$ 100,000$ to $\$ 499,999,7 \%$ earn $\$ 500,000$ to $\$ 999,999,6.5 \%$ earn $\$ 1$ million to $\$ 4.9$ million, and $10.4 \%$ earn over $\$ 5$ million.

\section{Measurement, reliability and validity of scales}

Seven-point Likert-type scales were used to develop constructs for the study. Measurement scales had with reliable psychometric properties, validated in previous empirical studies. Reliability for each scale was determined using Cronbach's alpha. The reliability score is a measure of the internal consistency of the construct (Nunnally, 1978), and alpha values over 0.70 indicates sound reliable measures.

Construct validity was assessed in using factor analysis described by Deshpande (1982). Principal component factor analysis provided factor loadings in order to assess construct validity. The factor loadings of the operationalized measurement scales provided indication of discriminant and convergent validity of the constructs. Although the determination of the cutoff point for assessment of validity is the researcher's choice, several researchers suggest that convergent validity is attained when factor loadings are $\geq 0.70$ (Bagozzi, 1981; Nunnally, 1967) and the average variance extracted for each factor component is $\geq 50 \%$ (Anderson and Gerbing, 1988).

\subsection{Entrepreneurial orientation scale}

The concept of entrepreneurial orientation (EO) used is based on the work of Miller (1983) and subsequently used by Covin and Slevin (1989). The EO construct used the three dimensions of innovativeness, risk taking, and proactiveness to characterize the degree of a firm's entrepreneurial orientation. In the EO scale, each dimension contains three items; thus, there are in all nine items. Many researchers have used this construct, resulting in high levels of reliability and validity measures (Covin and Slevin, 1989; Ripolles-Melia et al., 2007; Zahra et al., 2005; Zhou, 2007). The format used is a Likert scale requiring the respondents to choose a position based on a 1 to 7 range.

Based on the item purification process, we deleted two items. We then subjected the seven-item, higher entrepreneurial orientation scale to confirmatory factor analysis (CFA). The scale's CFA fit indices were good (chi-square/d.f. $=1.74, \mathrm{CFI}=0.96, \mathrm{NFI}=0.92$, RMSE $=0.07$ ), and in support of the second order factorial structure. The entrepreneurial orientation scale reliability estimate of 0.78 for the current study falls in the range of 0.77 to 0.88 in prior research (Matsuno et al., 2002).

\subsection{Management commitment scale}

The management commitment scale measuring the attitude towards internationalization consisted of three items, obtained from Cadogan et al. (2001). Each item was measured using a seven point Likert scale ranging from 1 to 7 ( $1=$ Strongly Disagree, $7=$ Strongly Agree). The items focus on the manager's commitment to the importance of internationalization. All the items loaded on a single factor, accounting for $90 \%$ of the variance. This scale possessed excellent internal consistency with a Chronbach's alpha of 0.96 (Nunnally, 1978).

\subsection{Market turbulence scale}

The market turbulence scale, based on Jaworski and Kohli (1993) was composed of four items. Each item was measured using a scale ranging from 1 to 7 , where 1 indicates that the respondent strongly disagrees with the statement and 7 indicates strong agreement with the statement. The scale's measurement properties have been found to show unidimensionality (e.g., Rose and Shoham, 2002). Based on the exploratory factor analysis, an item with low loading was removed. With the three items, the Cronbach's alpha was 0.72 , which was consistent with the previous studies.

\subsection{Human capital scale}

Human capital measured in the current study utilized the subjective measurement of the education level and international experience of employees of the firm (Dimov and Shepherd, 2005). Years of education and international experience have been used as proxy for human capital in prior studies (Dimov and Shepherd, 2005). Education was measured using a five-point ordinal scale. Respondents were asked to indicate the number of years of their involvement in international business as a measure of experience.

\subsection{Degree of internationalization measure}

International sales as a percentage of total sales is the most commonly used measure to capture the effectiveness of international performance (Yeoh, 2004). It is also a viable proxy for the degree of internationalization (Kumar and Singh, 2008; Sullivan, 1994). In this paper, an SME's degree of internationalization is considered when foreign sales represent more than $25 \%$ of total sales. Therefore, the dependent variable takes a value of one if an SMS's foreign sales are greater than 25\%; otherwise, it is zero (e.g., Ripolles-Melia et al., 2007).

Table 1 presents a summary of the measurement scales, sample item used for the constructs, and the reliability of the constructs.

\subsection{Control variables}

The three control variables used were firm size, age of the firm, and industry type. The number of employees defined the size of the firm and the firm's age was the number years since the company was established. Industry type was classified as manufacturing (coded as one) and service types (coded as zero).

\section{Methodology}

Logistic regression, used extensively in studies dealing with the choice of market entry modes as a method to predict the occurrence of the dependent variable (e.g., Erramilli and Rao, 1993) was used as the method of data analysis. 
Table 1

Sample items, source, and reliability of the constructs.

\begin{tabular}{|c|c|c|c|}
\hline Scale (Cronbach) & $\begin{array}{l}\# \text { of } \\
\text { Items }\end{array}$ & Sample Items & Prior Research \\
\hline $\begin{array}{l}\text { Entrepreneurial Orientation } \\
\quad(\text { Cronbach Alpha }=0.78)\end{array}$ & 7 & $\begin{array}{l}\text { - Strong emphasis on research, development, and innovation of products and technologies. } \\
\text { - Typically responds to actions which competitor initiate. } \\
\text { - Strong orientation for high-risk projects with chances of very high returns. }\end{array}$ & $\begin{array}{l}\text { Naman and Slevin, 1993; } \\
\text { Covin and Slevin, } 1989\end{array}$ \\
\hline $\begin{array}{l}\text { Management Commitment } \\
\quad(\text { Cronbach Alpha }=0.96)\end{array}$ & 3 & - Senior management in our company actively seeks international market opportunities. & Cadogan et al. (2001) \\
\hline $\begin{array}{l}\text { Market Turbulence } \\
\quad(\text { Cronbach Alpha }=0.72)\end{array}$ & 3 & - In our business, customers' product preferences change quite a bit over time. & Jaworski and Kohli (1993) \\
\hline Degree of Internationalization & 1 & - Percentage of foreign sates to total sales & $\begin{array}{l}\text { Zahra and Garvis, 2000; Lu anc } \\
\text { Beamish, 2001, 2004) }\end{array}$ \\
\hline $\begin{array}{l}\text { Human Capital } \\
\qquad(\# \text { of items }=2)\end{array}$ & 2 & - Education level and experience & Dimov and Shepherd (2005). \\
\hline
\end{tabular}

The functional formulation of the logistic regression can be expressed as follows:

$\mathrm{P}($ mode choice $=1)=\left[1 /\left(1+\mathrm{e}^{-\mathrm{Z}}\right)\right]$
Where, $\mathrm{Z}=\beta+\beta \mathrm{X}_{1}+\beta \mathrm{X}_{2}+\beta \mathrm{X}_{3}+\ldots \ldots \ldots+\beta \mathrm{X}_{\mathrm{k}}$

With X's being the explanatory variables.

\section{Results}

The analysis examined the correlations of the variables used in the study (see Table 2). None of the correlations appeared to be large enough to warrant concern about the issue of multicollinearity (Hair et al., 1998).

Table 3 provides the estimation results of the predictor for degree of internationalization. As can be seen from Table 3, the percent of cases classified is $78 \%$, indicating the fact that the independent variable is a good predictor of the degree of internationalization variable. As shown in Table 3 , both education level (beta $=0.68$, $p<0.01$ ) and international experience (beta $=0.41, p<01$ ) were significant; thus confirming that human capital is positively related to the degree of internationalization, confirming hypotheses H1. In addition, management commitment to internationalization was also significant (beta $=0.09, p<0.05$ ), confirming hypothesis $\mathrm{H} 2$. The results also provide support for $\mathrm{H} 3$, which confirms that entrepreneurial orientation is positively related to the degree of internationalization (beta $=0.32 ; p<0.01$ ).

As shown in Table 3, the coefficient of the moderator variable was not significant (beta $=0.03, p<0.30$ ); however, the coefficient of the multiplicative interaction term (interaction between entrepreneurial orientation and market turbulence) was significant (beta $=0.59$,

Table 2

Correlation matrix.

\begin{tabular}{llllllllll}
\hline Variables & 1 & 2 & 3 & 4 & 5 & 6 & 7 & 8 & 9 \\
\hline 1. DOI & 1 & & & & & & & & \\
2. Mgt.Com. & $0.26^{\mathrm{a}}$ & 1 & & & & & & & \\
3. EO & $0.16^{\mathrm{a}}$ & 0.02 & 1 & & & & & & \\
4. Mkt.Turb. & 0.10 & 0.04 & 0.05 & 1 & & & & & \\
5. Edu. & $0.16^{\mathrm{a}}$ & 0.09 & 0.03 & 0.04 & 1 & & & & \\
6. Int'l. Exp. & $0.25^{\mathrm{a}}$ & $0.26^{\mathrm{b}}$ & 0.09 & $0.13^{\mathrm{a}}$ & 0.11 & 1 & & & \\
7. Age & 0.06 & $0.32^{\mathrm{a}}$ & 0.02 & $0.15^{\mathrm{a}}$ & 0.10 & $0.45^{\mathrm{a}}$ & 1 & & \\
8. \# of Emp. & 0.03 & 0.08 & $-0.20^{\mathrm{a}}$ & $-0.21^{\mathrm{a}}$ & $0.18^{\mathrm{a}}$ & 0.04 & 0.05 & 1 & \\
9. Ind. type & 0.01 & 0.02 & 0.02 & 0.02 & 0.07 &, 01 & 0.03 & 0.12 & 1 \\
\hline
\end{tabular}

$\mathrm{DOI}=$ degree of internationalization; Mgt. Com = management commitment; $\mathrm{EO}=$ entrepreneurial orientation; Mkt. Trb. = market turbulence; Edu = level of education = Int'l. Exp. = international experience; Age = age of the firm; \# of Emp. = number of employees; Ind. Type = industry type.

a $p<0.05$.

b $p<0.01$. $p<0.01$ ), confirming hypothesis H4a. This situation implies that the moderator variable (market turbulence) modifies the relationship between entrepreneurial orientation and criterion variable (degree of internationalization). The interaction terms related to market turbulence and human capital (e.g., education and international experience) were not statically significant, thus hypothesis H4b was not supported.

\section{Discussion and conclusions}

\subsection{Managerial and theoretical implications}

India, considered an emerging market, is playing an important role in the international marketplace. Focusing on India, this study offers several important managerial and research implications. From a research standpoint, results provide an interesting addition to the existing body of knowledge about the strategic importance of entrepreneurial orientation, management commitment to internationalization and human capital in explaining the internationalization efforts of SMEs in the emerging market of India. The hypothesis that human capital is positively related to the degree of internationalization of Indian SMEs is supported by the results of this study. Educational level and international experience were significant as predictors of the degree of internationalization of the firm. Researchers Johanson and Vahlne (1990), for example, point out that firms that have some experience in international markets will tend engage in more internationalization efforts.

The management commitment to internationalization is also positively related to the degree of internationalization of SMEs in India. Previous studies have indicated that management commitment

Table 3

Logistic regression results.

\begin{tabular}{lc}
\hline Variables & Parameter Estimates \\
\hline Human capital (HC) & $0.68^{\mathrm{b}}$ \\
Education level (EDU) & $0.41^{\mathrm{a}}$ \\
International experience (IEXP) & $09^{\mathrm{a}}$ \\
Management commitment & $0.32^{\mathrm{b}}$ \\
Entrepreneurial orientation (EO) & 0.03 \\
Market turbulence (MT) & \\
Moderator & $0.59^{\mathrm{b}}$ \\
MT x EP & 0.02 \\
MT X IEXP & 0.04 \\
MT x EDU & \\
Control variables & $0.48^{\mathrm{a}}$ \\
Age of the firm & 0.09 \\
Size & 0.11 \\
Industry type & -2 \\
\hline
\end{tabular}

Percent of case: correctly classified $=78 \%$. Chi-Square $=33.95$. $-2 \log$ likelihood $=$ 86.39 .

b $P<0.01$

a $P<0.05$. 
to internationalize has a significant impact on export performance (Knight, 2001; Kuivalainen et al., 2004). Owners/managers of SMEs who implement programs to foster positive attitude towards expanding internationally among employees and demonstrate the importance of thinking outside the domestic market will improve the probability of success and create a competitive advantage. In addition, Indian SMEs must leverage resources such as human capital for their international marketing strategy in order to seize enormous opportunities in the global market.

For Indian SMEs, there is a strong link between entrepreneurial orientation and the degree of internationalization. Once again, the findings support previous research on relationships between entrepreneurial orientation and international expansion (Autio et al., 2000; Zucchella et al., 2007). The importance of the significant relationship between entrepreneurial orientation and degree of internationalization suggests that top management must foster entrepreneurial culture and international mindset throughout the organization.

In a study of ninety-eight U.S. international firms, Zahra and Garvis (2000) found that perceived characteristics of the international environment, in particular market turbulence/hostility, or in the case of Indian firms, governmental policy changes will significantly moderate the relationship between international corporate entrepreneurship and performance. Therefore, when market turbulence is high, firm entrepreneurship can positively affect firm performance. Our findings support this view.

The control variables the size and age of firm found to be significant in explaining the internationalization of Indian SMEs. This seems to suggest that entrepreneurial SMEs that are growing in size and have successfully established themselves in the marketplace over time are able to leverage the experience and knowledge obtained over time as they plan international expansion (Zhou, 2007). Williams (2008) notes as SMEs grow older they will acquire greater knowledge of how foreign markets operate. The control variable industry type was not significant, suggesting that regardless of the industry type, Indian SMEs seem to internationalize successfully due to entrepreneurial orientation.

\subsection{Limitations and conclusions}

Although the phenomenon of firm's internationalization attracts the attention of many scholars, they devote little effort to understanding the effects of internationalization of SMEs, especially SMEs in emerging markets.

This study makes three contributions. First, the study augments current research on internationalization by including SMEs in emerging markets such as India. The study complements the existing research stream. Second, this study validates the findings related to internationalization, previously examined in the context of western economies. Third, working with the empirical data, this research provides a foundation or framework through the identification of behavioral characteristics (e.g., risk taking) that impact international growth in India positively and gives a small or medium-sized firm operating in an emerging market a way to develop competitive advantage in a highly dynamic business environment. This study enhances existing theories since the findings of this research are extendable to include SMEs, in emerging economies.

Although this study offers a theoretical framework and empirical support of the complex relationship among entrepreneurship, firm capabilities and resources (e.g., human capital) and internationalization, an ambitious effort such as this is not without its limitations. One clear limitation of this study is that its cross-sectional nature implies that conclusions are tentative. The relationship between entrepreneurial activity and internationalization needs to be measured at different points or in a longitudinal framework. A second limitation relates to the constructs used in this study. For instance, the variable human capital used in this study does not capture all aspects of human capital. Therefore, different constructs suggested in the literature may be used in understanding the internationalization process of SMEs in emerging markets. Third, the moderator tested in this study is based on the literature.

However, other moderators (e.g., technological intensity, competitive intensity) may be considered. While this study focuses on only India, more research is needed to test the relationships among SMEs' internationalization, entrepreneurial behavior, and firm resources (international experience, human capital) using other emerging markets.

Finally, the degree of internationalization used in this study is a single construct. A multidimensional construct may be used to test the underlying relationships. Uncovering differences with regard to entrepreneurial orientation and management commitment to international expansion between Indian managers and their foreign counterparts would extend this research. This uncovering may lead to a better understanding of the factors that contribute to successful international undertakings.

Another extension of this study could be collecting longitudinal data in multiple emerging markets. As SMEs in emerging markets continue to expand internationally, we feel that there is clear opportunity to develop a broad array of models based on theoretical underpinnings toward a comprehensive understanding of entrepreneurial internationalization behavior of SMEs in emerging markets.

\section{References}

Anderson JC, Gerbing DW. Structural equation modeling in practice: a review and recommended two-step approach. Psychol Bull 1988;103(3):411-23.

Athanassiou N, Nigh D. The impact of the top management team's international business experience on the firm's internationalization: social network at work. Manage Int Rev 2002;42(2):157-81.

Autio E, Sapienza HJ, Almeida JG. Effects of age at entry, knowledge intensity, and imitability on international growth. Acad Manage J 2000;43(5):909-24.

Bagozzi RP. Evaluating structural equation models with unobservable variables and measurement error: a comment. J Mark Res 1981;18(3):375-81.

Barney J. Firm's resources and sustained competitive advantage. J Manage 1991;1(1): 99-120.

Benito, Gabriel RG, Petersen B, Welch LS. Toward more realistic conceptualizations of foreign operations modes. J Int Bus Stud 2009;40:1455-70.

Bosma N, Van Praag M, Thurik R, de Wit G. The value of human capital and social capital investments for the business performance of start-ups. Small Bus Econ 2004;23: 227-36.

Brush C, Chaganti R. Business without glamor? An analysis of resources on performance by size and age in small service retail firms. J Bus Venturing 1998;14:233-57.

Bruton GD, Ahlstrom D, Obloj K. Entrepreneurship in emerging economies: where are we today and where should the research go in the future. Entrep Theory Pract 2008;32(1):1-14

Buckley PJ, Casson MC. The future of the multinational enterprise. London: Macmillan; 1976.

Buckley PG, Casson MC. The internationalization theory of the multinational enterprise: a review of the progress of a research agenda after 30 years. J Int Bus Stud 2009;40: 1563-80.

Cadogan JW, Paul N, Salminen RT, Puumalainen K, Sandqvist S. Key antecedents to export market-oriented behaviors: a cross-national empirical examination. Int J Res Mark 2001;18(3):261-82.

Cadogan JW, Sundqvist S, Salminen RT, Puumalainen K. Export marketing, interfunctional interactions, and performance consequences. J Acad Mark Sci 2005;33(4): 520-35.

Calof JL, Beamish PW. Adapting to foreign markets: explaining internationalization. Int Bus Rev 1995;4(2):115-32.

Cavusgil ST, Naor J. Firm and management characteristics as discriminators of export marketing activity. J Bus Res 1987;15(3):221-35.

Churchill GA. A paradigm for developing better measures of marketing constructs. J Mark Res 1979;16:64-73 (February).

Coleman J. Social capital in creation of human capital. Am J Sociol 1998;94:95-120.

Covin JG, Slevin DP. The influence of organization structure on the utility of an entrepreneurial top management style. J Manage Stud 1988;25(3):217-34

Covin JG, Slevin DP. Strategic management of small firms in hostile and benign environments. Strat Manage J 1989;10:75-87.

Crick D, Jones MV. Small high-technology firms and international high-technology markets. J Int Mark 2000;8(2):63-85.

Deshpande R. The organizational context of market research use. J Mark 1982;46(4): 91-101.

Dimov D, Shepherd D. Human Capital Theory and venture capital firms: exploring home runs and strike outs. J Bus Venturing 2005;20(1):1-21.

Doh JP. Offshore outsourcing: implications for international business and strategic management theory and practice. J Manage Stud 2005:695-704. 
Dunning JH. Toward an Eclectic Theory of international production: some empirical tests. J Int Bus Stud 1980:9-31.

Dunning JH. International Production and the Multinational Enterprise. London: Allen and Unwin; 1981.

Erramilli MK, Rao CP. Service firms' international entry-mode choice: a modified transaction-cost analysis approach. J Mark 1993;57(3):19-39.

Fletcher D. International entrepreneurship and small business. Entrepreneurship Reg Dev 2004;16:289-305 (July).

Gregorio DD, Musteen, Thomas DE. Offshore outsourcing of international competitiveness for SMEs. J Intl Bus Stud 2008:1-19.

Hair, Anderson, Tatham, Black. Multivariate data analysis. 5th edition. New Jersey: Prentice Hall; 1998.

Heide JB, Weiss AM. Vendor consideration and switching behavior for buyers in hightechnology markets. J Mark 1995;59(3):30-44.

Herrmann P, Datta D. Relationships between top management team characteristics and international diversification: an empirical investigation. Br J Manage 2005;16: 69-78.

Hitt MA, Hoskisson RE, Kim H. International diversification: effects on innovation and firm performance in product-diversified firms. Acad Manage J 1997;40(4):767-98.

Hutchinson K, Quinn B, Alexander N. SME retailer internationalization: case study evidence from British retailers. Int Mark Rev 2006;23(1):25-53.

Ibeh KIN. Toward a contingency framework of export entrepreneurship: conceptualisations and empirical evidence. Small Bus Econ 2003;20:49-68.

Ibeh KIN, Young S. Exporting as an entrepreneurial act an empirical study of Nigerian firms. Eur J Mark 2001;35(5/6):566-86.

Javalgi RG, Disit A, Scherer RF. Outsourcing to emerging markets: theoretical perspectives and policy implications. J Int Mark 2009;15:156-68.

Jaworski BJ, Kohli AK. Market orientation: antecedents and consequences. J Mark 1993:57:53-70.

Johanson J, Mattsson LG. Internationalization in industrial systems - a network approach. In: Hood N, Vahlne JE, editors. Strategies in Global Competition. NY: Croom Helm; 1988. New York.

Johanson J, Vahlne JE. The mechanism of internationalization. Int Mark Rev 1990;7(40): 11-24.

Kaya N, Seyrek IH. Performance impacts of strategic orientation: evidence from Turkish manufacturing firms. J Am Acad Bus 2005:68-72 March.

Kedia BL, Mukherji A. Global managers: developing a mindset for global competitiveness. J World Bus 1999;34(3):230-51.

Knight G. Entrepreneurship and strategy in the international SME. J Int Manage 2001;7: 155-71.

Knight G, Cavusgil T. Innovation organizational capabilities and the born global firm. J Inter Bus Stud 2004;2:124-41.

Kohli AK, Jaworski BJ. Market orientation: the construct, research propositions, and managerial implications. J Mark 1990;54:1-18 (April).

Kuivalainen O, Sundqvist S, Puumalainen K, Cadogan JW. The effect of environmental turbulence and leader characteristics on international performance: are knowledge-based firms different? Can J Admin Sci 2004;21(1):35-50.

Kumar V, Singh N. Internationalization and performance of Indian pharmaceutical firms. Int Bus Rev 2008;50(5):321-30.

Leonidou LC, Katsikeas CS, Piercy NF. Identifying managerial influence on exporting: past research and future directions. J Int Mark 1998;6(2):74-102.

Loscocco K, Robinson J, Hall R, Allan J. Gender and small business success: an inquiry into women's relative advantage. Soc Forces 1991;70:65-85.

Lu JW, Beamish PW. The internationalization and performance of SMEs. Strateg Manage J 2001;22:565-86.

Lu JW, Beamish PW. International diversification and firm performance: the S-Curve hypothesis. Acad Manage J 2004:47(4):598-609.

Lumpkin GT, Dess GG. Clarifying the entrepreneurial orientation construct and linking it to performance. Acad Manage Rev 1996;21(1):135-72.

Luo X, Zhou L, Liu SS. Entrepreneurial firms in the context of China's transition economy: an integrative framework and empirical examination. J Bus Res 2005: 277-84.

Manolova T, Brush CG, Edelman L, Greene PG. Internationalization of small firms. Int Small Bus J 2002;20(1):9-31.

Matsuno K, Mentzer JT, Ozsomer A. The effects of entrepreneurial proclivity and market orientation on business performance. J Mark 2002;66(3):18-32.

McDougall PP, Oviatt BM. International entrepreneurship: the intersection of two research paths. Acad Manage J 2000;43(5):902-6.
McDougall PP, Covin JG, Robinson Jr RB, Herron L. The effects of industry growth and strategic breadth on new venture performance and strategy content. Strateg Manage J 1994;15(7):537-54.

McDougall PP, Oviatt BM, Schrader RC. A comparison of international and domestic new ventures. J Int Entrep 2003;1(1):59-82.

Miller D. The correlation of entrepreneurship in three types of firms. Manage Sci 1983;29(7):770-91.

Naman JL, Slevin DP. Entrepreneurship and the concept of fit: A model and empirical tests. Strategic Manage J 1993;14(2):137-53.

Nunnally JC. Psychometric theory. New York, NY: McGraw Hill; 1967.

Nunnally JC. Psychometric theory. 2nd edition. New York: McGraw Hill; 1978.

Patterson PG, Cicic M. A typology of service firms in international markets: an empirical investigation. J Int Mark 1995;3(4):57-83.

Prahalad CK, Hamel G. The core competence of the corporation. Harvard Bus Rev 1990;68(3):79-91.

Ripolles-Melia M, Menguzzato-Boulard M, Sanchez-Peinado L. Entrepreneurial orientation and international commitment. J Internat Commitment 2007;5:65-83.

Rose GM, Shoham A. Export performance and market orientation: establishing an empirical link. J Bus Res 2002;55(3):217-25.

Ruzzier M, Antoncic B, Hisrich RD, Konecnik M. Human capital and SME internationalization: a structural equation modeling study. Can J Admin Sci 2007;24(1):15-29.

Spence M. Crick D. A comparative investigation into the internationalisation of Canadian and UK high-tech SMEs. Int Mark Rev 2006;23(5):524-48.

Sullivan D. Measuring the degree of internationalization of a firm. J Int Bus Stud 1994;25:323-42.

Todd P, Javalgi R. Internationalization of SMEs in India: fostering entrepreneurship by leveraging information technology. Int J Emerg Mark 2007;2(2):166-80.

Venkataramany S. Globalization of entrepreneurship: overwhelming institutional response in favor of SME in India. EABR and TLC Conf Proc; 2008.

Wernerfelt B. The resource-based view of the firm: ten years after. Strateg Manage J 1995;16(3):171-4.

Wiklund J, Shepherd D. Knowledge-based resources, entrepreneurial orientation, and the performance of small and medium-sized businesses. Strateg Manage J 2003;24: 1307-14.

Williams DA. Export stimulation of micro-and small locally owned firms from emerging environments: new evidence. J Int Entrep 2008;6:101-22.

Winsted K, Patterson PG. Internationalization of services: the service exporting decision. J Serv Mark 1998;12(6):294-312.

Yeoh P. Antecedents and performance implications among newly internationalized companies in an exporting context. Int Mark Rev 2004;21(4/5):511-35.

Yeoh P, Jeong I. Contingency relationships between entrepreneurship, export channel structure and environment. Eur J Mark 1995;29(8):95-115.

Yiu DW, Chung ML, Bruton GD. International venturing by emerging economy firms: the effects of firm capabilities, home country networks, and corporate entrepreneurship. J Int Bus Stud 2007;38(4):519-40.

Zahra SA, Garvis DM. International corporate entrepreneurship and firm performance: the moderating effect of international environmental hostility. J Bus Venturing 2000;15:469-92.

Zahra SA, George G. International entrepreneurship: the current status of the field and future research agenda. In: Hitt MA, Ireland RD, Camp SM, Sexton DL, editors. Strategic Entrepreneruship: Creating a new mindset. Blackwell Oxford; 2002. p. $255-88$.

Zahra SA, Neubaum DO. Environmental adversity and entrepreneurial activities of new ventures. J Dev Entrep 1998;3(2):123-40.

Zahra SA, Korri JS, Yu. Cognition and international entrepreneurship: implications for research on international opportunity recognition and exploitation. Int Bus Rev 2005; 14:129-46.

Zhou L. The effects of entrepreneurial proclivity and foreign market knowledge on early internationalization. J World Bus 2007;42(3):281-93.

Zucchella A, Palamara G, Denicolai S. The drivers of the early internationalization of the firm. J World Bus 2007;42(3):268-80. 